\title{
Lung isolation for the prevention of air embolism in penetrating lung trauma. A case report
}

Anthony M.-H. Ho MD MS FRCPC, Sumin Lee MBBS, Beng A. Tay MBBCH FFARCSI, David C. Chung MD FRCPC

Purpose: To illustrate a new airway and ventilatory management strategy for patients with unilateral penetrating lung injury. Emphasis is placed on avoiding positive pressure ventilation (PPV)-induced systemic air/gas embolism (SAE) through traumatic bronchiole-pulmonary venous fistulas.

Clinical Features: A 14-yr-old male, stabbed in the left chest, presented with hypovolemia, left hemopneumothorax, an equivocal acute abdomen, and no cardiac or neurological injury. In view of the risk of SAE, we did not ventilate the left lung until any fistulas, if present, had been excised. After pre-oxygenation, general anesthesia was induced and a left-sided double-lumen tube (DLT) was placed to allow right-lung ventilation. Bronchoscopy was performed. The surgeons performed a thorascopic wedge resection of the lacerated lingula. Upon completion of the repair, two-lung ventilation was instituted while the ECG, pulse oximetry, $\mathrm{P}_{\mathrm{ET}} \mathrm{CO}_{2}$, and blood pressure were monitored. Peak inflation pressure was increased slowly and was well tolerated up to 50 $\mathrm{cm} \mathrm{H}_{2} \mathrm{O}$. The patient's intravascular status was maintained normal.

Conclusion: Patients with lung trauma are at risk of developing SAE when their lungs are ventilated with PPV. In a unilateral case, expectant non-ventilation of the injured lung until after repair is recommended.

Objectif : Illustrer une nouvelle façon de protéger les voies aériennes et d'assurer la ventilation chez des patients victimes de lésions pulmonaires unilatérales par pénétration. On veut surtout éviter l'aéroembolie ou l'embolie gazeuse systémique (AES) induite par la ventilation à pression positive (VPP) au travers de fistules bronchioliques et veineuses pulmonaires.

Éléments cliniques : Un garçon de 14 ans, poignardé au côté gauche, présentait une hypovolémie, un hémopneumothorax gauche, un abdomen aigu possible, mais aucune lésion cardiaque ou neurologique. Étant donné le risque d'AES, la ventilation du poumon gauche a été retardée jusqu'à ce que toute fistule possible ait été excisée. Après une pré-oxygénation, l'anesthésie générale a été induite et un tube à double lumière gauche (TDL) a été inséré pour permettre la ventilation du poumon droit. On a procédé à une bronchoscopie. Les chirurgiens ont réalisé une résection cunéiforme thoracoscopique de la lingula lacérée. Une fois la réparation terminée, la ventilation bipulmonaire a été instaurée tandis que l'ECG, l'oxymétrie pulsée, la $\mathrm{P}_{\mathrm{ET}} \mathrm{CO}_{2}$ et la tension artérielle étaient placés sous monitorage. La pression de distension maximale a été augmentée lentement et a été bien tolérée jusqu'à $50 \mathrm{~cm} \mathrm{H} \mathrm{H}_{2} \mathrm{O}$. L'état intravasculaire a été maintenu normal.

Conclusion : Les patients victimes de traumatisme pulmonaire sont à risque de subir une AES lorsque leurs poumons sont ventilés sous une VPP. Dans le cas d'un traumatisme unilatéral, il est recommandé de ne pas utiliser la ventilation du poumon lésé avant la fin de la réparation.

From the Department of Anaesthesia and Intensive Care, Faculty of Medicine, The Chinese University of Hong Kong, Shatin, NT, Hong Kong SAR, PRC.

Address correspondence to: Anthony Ho MD, Department of Anaesthesia and Intensive Care, Prince of Wales Hospital, Shatin, NT,

Hong Kong SAR, PRC. Phone: 852-2632-2735; Fax: 852-2637-2422; E-mail: hoamh@hotmail.com Accepted for publication September 5, 2000. 


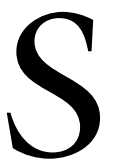

YSTEM air/gas embolism (SAE) after lung trauma can occur via direct channels created between air and blood conduits. ${ }^{1-13}$ Positive pressure ventilation (PPV), tension pneumothorax, coughing, and hypovolemia promote SAE development. Typically, SAE presents as circulatory collapse/stroke immediately after tracheal intubation and initiation of PPV. ${ }^{1-12}$ The condition occurs in 4$14 \%$ of serious chest trauma cases. ${ }^{2,14}$ Recommended management involves immediate thoracotomy for hilar clamping of the injured lung. ${ }^{2,4,14}$ The associated mortality and morbidity rates are high. Yee et al. found that mortality rates for SAE from penetrating trauma was $48 \%{ }^{2}$ Baker et al. found that of those who arrested because of SAE requiring emergency thoracotomy, $91 \%$ died. ${ }^{12}$ We have argued that anesthesiologists can play a pivotal role in improving the outcome of such patients. ${ }^{15}$ The following case illustrates a new concept of airway and ventilatory management for prevention of SAE after unilateral chest trauma.

\section{Case report}

A 14-yr-old, $158 \mathrm{~cm}, 60 \mathrm{~kg}$ male was stabbed. The wound was $4 \mathrm{~cm}$ long, just lateral to the left nipple. The knife entered the pleural cavity two rib spaces below, severing intercostal bundles. He presented with mild hypotension, tachycardia, tachypnea, left hemopneumothorax, and an equivocal acute abdomen. There was no cardiac murmur, neurological deficit or hemoptysis. Chest X-ray (Figure 1) revealed a hemopneumothorax, left rib fractures, and a normal mediastinum. Electrocardiogram (ECG) showed sinus tachycardia. Breathing $50 \% \mathrm{O}_{2}$, pulse oximetry registered $98 \%$. His hemoglobin was $104 \mathrm{~g} \cdot \mathrm{L}^{-1}$, and his platelet count and coagulation indexes were normal. He was fluid resuscitated and received a left chest tube. Emergency left thoracoscopy was planned.

The anesthetic concerns included mediastinal and pulmonary injuries. After adequate pre-oxygenation and placement of a 14-G intravenous cannula, an arterial line and other monitors, anesthesia was induced in rapid sequence with cricoid pressure using $100 \mu \mathrm{g}$ fentanyl, $175 \mathrm{mg}$ thiopentone, and $100 \mathrm{mg}$ succinylcholine, and a 35 French left-sided double-lumen tube (DLT) was placed at the first attempt down to a depth of $28 \mathrm{~cm}$. Both DLT cuffs, earlier checked, were immediately inflated and the patient was given right-lung ventilation, starting at low pressures $(<20$ $\mathrm{cm} \mathrm{H}_{2} \mathrm{O}$ peak). Auscultation was consistent with correct placement. The left lung was never ventilated. Bronchoscopy was performed to confirm the DLT position and to assess the airway. The left bronchial tree was visualized to the bifurcation of the superior

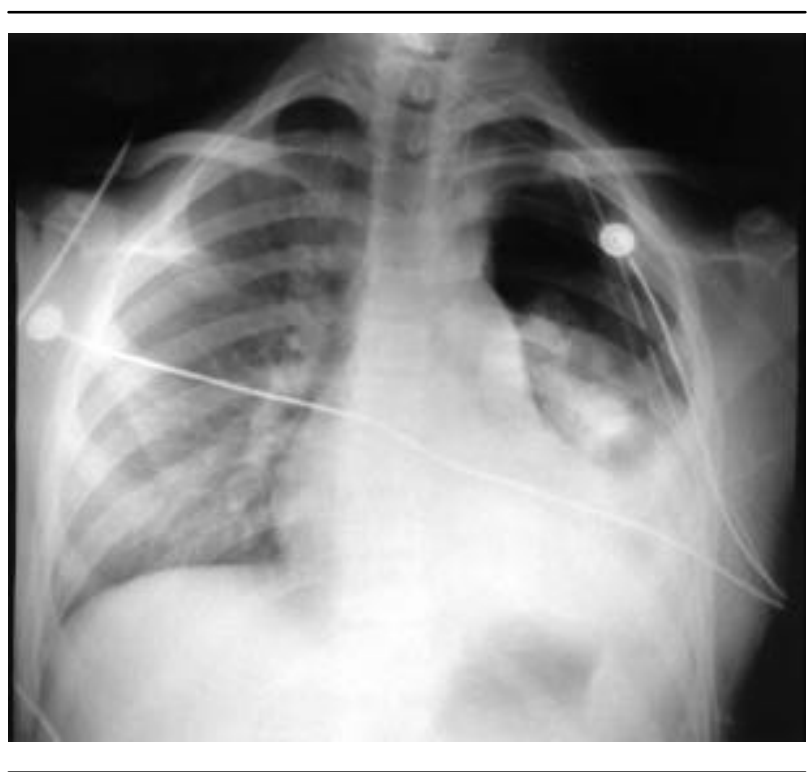

FIGURE Chest X-ray of patient showing normal mediastinum, fractured ribs, and hemopneumothorax.

and inferior segmental bronchi of the lingular lobe, and was normal and free of blood or foreign material. Upon confirmation of the DLT position, the right lung ventilatory pressure was increased to a peak of 30 $\mathrm{cm} \mathrm{H}_{2} \mathrm{O}$. A thorascopic wedge resection of the lingula, which was lacerated, was performed. A pulsating intercostal artery was cauterized, and blood was suctioned from the chest. As there was a laceration of the left hemi-diaphragm, laparoscopy was performed, which found no intra-abdominal injury. After the lacerated lingual segment was removed, two-lung ventilation was commenced while monitoring the ECG, pulse oximetry, $\mathrm{P}_{\mathrm{ET}} \mathrm{CO}_{2}$, and blood pressure. Peak inflation pressure was increased slowly and was well tolerated up to $50 \mathrm{~cm} \mathrm{H}_{2} \mathrm{O}$. The patient's intravascular status was maintained with infusion of fluids. The patient's trachea was extubated at the end of the case. He was discharged home five days later.

\section{Discussion}

The classic presentation of traumatic SAE is hemoptysis following lung trauma and circulatory and/or cerebral dysfunction immediately after initiation of PPV. ${ }^{14}$ Gas in the retinal vessels, arterial aspirates, left heart, or cerebral vessels all confirm SAE.14,15 Gas emboli cause obstruction and local inflammation. ${ }^{16}$ In coronary and cerebral arteries, 1-2 mL of gas can be fatal. ${ }^{15}$

A MEDLINE search from 1966 revealed 104 mostly fatal cases of SAE after penetrating lung trauma; ${ }^{1-13,15}$ no mention of one-lung ventilation was 
made in any of them. The avoidance of SAE through lung isolation is a new concept in unilateral lung trauma management, ${ }^{15}$ and could have been a major factor in the favourable outcome of this patient. Without such considerations, bilateral PPV would usually have been instituted once the airway was secured, with potentially disastrous consequences.

Although the Univent ${ }^{\circledR}$ tube is, in general, more suitable in trauma patients ("full stomach" and possibility of cervical spine injury), we chose the DLT such that we could bronchoscope as well as suction out blood in the bronchus of the injured lung without interruption of ventilation of the uninjured lung. Had a standard tracheal tube been in place already, the most appropriate lung isolation choice would probably have been a bronchial blocker. We did not check with bronchoscopy before the first assisted breath of the uninjured lung after DLT placement to avoid desaturation, but we did the next best thing by initially ventilating only that side at low pressures and increasing to higher pressures only after an apparently uncomplicated DLT placement, and after auscultating and checking with a bronchoscope.

It is difficult to predict who will develop SAE upon institution of PPV. The lack of hemoptysis does not preclude SAE as it occurs in only $16-25 \%$ of cases. ${ }^{2,17}$ Injuries close to the hilar region yield the highest risk because that is where the pulmonary vein lies in close proximity to the airway branches. ${ }^{18}$ Lack of proximal injury and blood in the bronchial tree was assessed with bronchoscopy in our case. Coupled with the assurance that all lung lacerations had been excised, we were only then willing to institute bilateral PPV for the first time in this patient. Ideally, transesophageal echocardiography during gradual increase of airway pressure would detect gas emboli as soon as it occurs. The time it takes for conservatively managed traumatic bronchiole-pulmonary venous fistulas to close is unknown. In general, one should delay PPV for as long as possible, and to normalize homeostasis early. High pressures in the injured lung and hypovolemia should be avoided. High frequency ventilation may be considered. ${ }^{15}$ Regional anesthesia, while not appropriate for our case, is preferred over general anesthesia. $\mathrm{N}_{2} \mathrm{O}$ is contraindicated and $100 \% \mathrm{O}_{2}$ promotes emboli resorption. Transportation, preferably on land, to a hyperbaric facility for treatment of cerebral gas embolism may be required once the initial resuscitation and surgical repair have been completed.

\section{References}

1 Thomas $A N$. Air embolism following penetrating lung injuries. J Thorac Cardiovasc Surg 1973; 66: 533-40.
2 Yee ES, Verrier ED, Thomas AN. Management of air embolism in blunt and penetrating thoracic trauma. J Thorac Cardiovasc Surg 1983; 85: 661-8.

3 Thomas AN, Stephens BG. Air embolism: a cause of morbidity and death after penetrating chest trauma. J Trauma 1974; 14: 633-8.

4 Graham JM, Beall AC Jr, Mattox KL, Vaughan GD. Systemic air embolism following penetrating trauma to the lung. Chest 1977; 72: 449-53.

5 Estrera AS, Pass LJ, Platt MR. Systemic arterial air embolism in penetrating lung injury. Ann Thorac Surg 1990; 50: 257-61.

6 Donato AT, Arciniegas E, Lam CR. Fatal air embolism during thoracotomy for gunshot injury to the lung. J Thorac Cardiovasc Surg 1975; 69: 827-9.

7 Smith JM III, Richardson JD, Grover FL, Arom KV, Webb GE, Trinkle JK. Fatal air embolism following gunshot wound of the lung. J Thorac Cardiovasc Surg 1976; 72: 296-8.

8 Campbell PR, Kerridge R. Fatal traumatic air embolism following a stab wound to the chest. Aust NZ J Surg 1993; 63: 307-9.

9 Hewitt PM, Knottenbelt JD, Mortimore S. Combined systemic and pulmonary air embolism after penetrating chest injury. Injury 1994; 25: 553-4.

10 Halpern P, Greenstein A, Melamed $\Upsilon$, Taitelman U, Sznajder I, Zveibil F. Arterial air embolism after penetrating lung injury. Crit Care Med 1983; 11: 392-3.

11 Enneking TJMQ van der Werken C, de Waal Malifijt J. Bone necrosis of the femoral head after thoracic trauma. Injury 1994; 25: 122-3.

12 Baker CC, Thomas AN, Trunkey DD. The role of emergency room thoracotomy in trauma. J Trauma 1990; 20: 848-55.

13 King MW, Aitchison JM, Nel JP. Fatal air embolism following penetrating lung trauma: an autopsy study. J Trauma $1984 ; 24: 753-5$.

14 Trunkey $K$ Initial treatment of patients with extensive trauma. N Engl J Med 1991; 324: 1259-63.

15 Ho AM-H, Ling E. Systemic air embolism after lung truama. Anesthesiology 1999; 90: 564-75.

16 Muth CM, Shank ES. Gas embolism. N Engl J Med 2000; 242: 476-82.

17 Battistella FD, Benfield JR. Blunt and penetrating injuries of the chest wall, pleura, and lungs In: Shields TW, LoCicero J III, Ponn B (Eds.). General Thoracic Surgery, 5th ed. Philadelphia: Lippincott Williams \& Wilkins, 2000: 823.

18 Wiencek RG Jr, Wilson RF. Central lung injuries: a need for early vascular control. J Trauma 1988; 28 : 1418-24. 